\title{
Use of glucocorticoids in patients with acute respiratory distress syndrome: a meta-analysis and trial sequential analysis
}

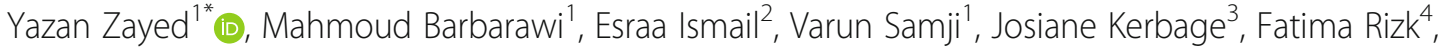 \\ Mohammad Salih', Areeg Bala', Michele Obeid', Smit Deliwala', Sherry Demian', Ibrahim Al-Sanouri ${ }^{5}$ \\ and Raju Reddy ${ }^{6}$
}

\begin{abstract}
Background: Acute respiratory distress syndrome (ARDS) is a common and disabling disease with high rates of mortality and morbidity. The role of steroids in treating ARDS remains controversial. We aim to examine the evidence behind using glucocorticoids in the management of ARDS from the available studies.

Methods: We performed a literature review of major electronic databases for randomized controlled trials (RCTs) comparing glucocorticoids versus placebo in treating patients with ARDS. Our primary outcome was hospital mortality. Other outcomes included ICU mortality, number of ventilator-free days at day 28 , incidence of nosocomial infections, and hyperglycemia. We performed a meta-analysis using a random effects model to calculate risk ratios (RR) and mean difference (MD) with their corresponding 95\% confidence intervals (CI). A subsequent trial sequential analysis was performed to examine the strength of evidence and to guard against statistical type I and type II errors for our results.
\end{abstract}

Results: Eight RCTs were included in the final analysis totaling of 1091 patients, with a mean age of $57 \pm 16$, and $56.2 \%$ were male. In our pooled analysis, use of glucocorticoids was associated with a significant reduction in hospital mortality (RR 0.79; $95 \% \mathrm{Cl} 0.64-0.98 ; P=0.03$ ) and ICU mortality (RR $0.64 ; 95 \% \mathrm{Cl} 0.42-0.97 ; P=0.04$ ). Furthermore, glucocorticoid use was associated with an increased number of ventilator-free days at day 28 (MD 4.06 days; 95\% Cl 2.66-5.45; $P<0.01$ ). Regarding adverse events, glucocorticoids use was not associated with an increased risk for nosocomial infections (RR 0.82; 95\% Cl 0.68-1.00; $P=0.05$ ); however, it was associated with an increased risk of hyperglycemia (RR $1.11 ; 95 \% \mathrm{Cl} 1.01-1.24 ; P=0.04$ ). In our trial sequential analysis, the required diversity-adjusted information size (sample size $=2692$ patients) was not reached, and the evidence was insufficient from the available RCTs.

Conclusion: Among patients with ARDS, use of glucocorticoids is associated with a significant reduction in mortality and duration of mechanical ventilation, without increased risk of hospital-acquired infections. However, based on a trial sequential analysis, these findings may be secondary to a false-positive (type I) error. Further studies are needed for a firm conclusion with guarding against possible statistical errors.

Keywords: Glucocorticoids, Corticosteroids, Acute respiratory distress syndrome, ARDS, Meta-analysis

\footnotetext{
*Correspondence: yzayed1@hurleymc.com; yz.alzayed@yahoo.com

${ }^{1}$ Department of Internal Medicine, Hurley Medical Center/Michigan State

University, One Hurley Plaza, Suite 212, Flint, MI 48503, USA

Full list of author information is available at the end of the article
}

\section{$\triangle B M C$}

(c) The Author(s). 2020 Open Access This article is licensed under a Creative Commons Attribution 4.0 International License, which permits use, sharing, adaptation, distribution and reproduction in any medium or format, as long as you give appropriate credit to the original author(s) and the source, provide a link to the Creative Commons licence, and indicate if changes were made. The images or other third party material in this article are included in the article's Creative Commons licence, unless indicated otherwise in a credit line to the material. If material is not included in the article's Creative Commons licence and your intended use is not permitted by statutory regulation or exceeds the permitted use, you will need to obtain permission directly from the copyright holder. To view a copy of this licence, visit http://creativecommons.org/licenses/by/4.0/. The Creative Commons Public Domain Dedication waiver (http://creativecommons.org/publicdomain/zero/1.0/) applies to the data made available in this article, unless otherwise stated in a credit line to the data. 


\section{Introduction}

Acute respiratory distress syndrome (ARDS) is a common and disabling syndrome with high rates of mortality and morbidity. It affects $10 \%$ of patients admitted to intensive care units (ICUs) and almost 23\% of mechanically ventilated patients. Additionally, ARDS has been found to have up to $35-45 \%$ mortality rate [1-3].

A recently published randomized controlled trial (RCT) showed a significant reduction in short-term and long-term mortality of ARDS patients who received dexamethasone within $24 \mathrm{~h}$ of ARDS onset [4]. In addition, an analysis involving individual patients' data of four randomized controlled trials (RCTs) showed significant improvement in mortality and several other clinical outcomes with glucocorticoid use in ARDS patients [5]. However, their use in ARDS is still controversial, and the current society of critical care medicine guidelines have conditional recommendations for the use of glucocorticoids in patients with moderate-to-severe ARDS [6].

In this meta-analysis, we aim to examine the efficacy and safety of glucocorticoids in ARDS, as well as examine the strength of current evidence based on the available RCTs by performing a trial sequential analysis.

\section{Methodology}

\section{Study design and study selection}

Our study is a meta-analysis of RCTs performed according to the Preferred Reporting Items for Systematic Reviews and Meta-Analyses Protocols (PRISMA-P) 2015 Statement [7]. Literature search utilizing major electronic databases including PubMed, Cochrane library, and Embase was conducted separately and independently by two reviewers (V.S.) and (M.S.) from inception to March 2020. Articles were first screened by abstracts and titles before exclusion. Review of full texts of eligible articles was performed before final inclusion or exclusion. Mesh term used: ("acute lung injury" OR "acute respiratory distress syndrome" OR "ARDS") AND ("glucocorticoids" OR "corticosteroid" OR "steroids" OR "methylprednisolone" OR "dexamethasone" OR "hydrocortisone" OR "prednisolone"). In addition, references of relevant articles were reviewed for possible inclusion. Any discrepancy between the two reviewers was resolved by a third author (Y.Z.).

\section{Inclusion and exclusion criteria}

We included only RCTs that evaluated the role of glucocorticoids in the management of critically ill adult patients with established respiratory failure secondary to ARDS; ARDS was defined as acute hypoxemic respiratory failure with presence of bilateral infiltrates on chest imaging, $\mathrm{PaO} 2 / \mathrm{FiO} 2<300$ without evidence of left ventricular failure or hydrostatic edema. Studies that examined prophylactic effects of glucocorticoids in patients at high risk for ARDS were excluded. In addition, we excluded studies with a high risk of bias as well as studies unavailable in English.

Two reviewers (E.I. and J.K.) extracted the data into predesigned tables independently and separately. Any discrepancy was resolved by a third reviewer (Y.Z.).

\section{Quality assessment}

Quality assessment of the included RCTs was performed using the Cochrane Collaboration's tool for assessing risk of bias in randomized controlled trials [8]. Random sequence generation, allocation concealment, blindness of participants and health-care personnel, blindness of outcome assessment, incomplete outcome data, selective reporting, and other biases if any were present were assessed for each of the included RCTs based on authors' judgement.

\section{Outcomes}

Our primary outcome was in-hospital mortality defined as mortality before hospital discharge (if in-hospital mortality was not provided, we utilized the 60-day mortality or mortality at longest follow-up duration provided by each study in order of preference). Secondary outcomes included ICU mortality and number of ventilator free days at day 28. Safety outcomes included incidence of nosocomial infections and incidence of hyperglycemia.

\section{Statistical analysis}

Pooled risk ratios (RR) with their corresponding 95\% confidence intervals (CI) for dichotomous data were calculated using the random Mantel-Haenszel method. We calculated weighted mean difference (MD) and their 95\% corresponding confidence intervals for continuous variables using an inverse variance test. Heterogeneity was assessed using Cochrane $\mathrm{Q}$ and $I^{2}$ tests. Sensitivity analysis was performed by sequential removal of trials for each outcome. In addition, we conducted a subgroup analysis based on timing of glucocorticoids administration, early (less than 7 days of ARDS onset) vs late ( $>7$ days of ARDS onset), severity of ARDS, and whether studies used lung protective ventilations or not. Further meta-regression analyses were performed based on the study-level covariates [age, duration of glucocorticoids treatment (days), daily dose of glucocorticoid equivalent to prednisone, age, mean positive end-expiratory pressure, partial pressure of arterial oxygen to fractional inspired oxygen $(\mathrm{PaO} 2 / \mathrm{FiO} 2)]$. Revman v5.3 windows and the Comprehensive Meta-Analysis v3 software were used for the analysis. 
Trial sequential analysis

To examine the strength of our results, we applied trial sequential analysis (TSA) boundaries to the meta-analysis to guard against the risk of falsepositive (type I error) or false-negative (type II error) results [9]. We performed our analysis to maintain an overall two-sided type I error at 5\% and to provide $80 \%$ power to calculate the diversity-adjusted information size in order to examine if the conclusion is sufficient or if further studies are needed to detect $20 \%$ relative risk reduction (RRR) of hospital and ICU mortality between the two groups. Further analyses were performed to calculate sample size required for $15 \%$ and $25 \%$ relative risk reduction of mortality. TSA software, Copenhagen Trial Unit, version 0.9.5.10 Beta was used to conduct the analysis.

\section{Results}

Summary of included studies

After review of electronic databases, we included 8 RCTs totaling 1091 patients with a mean age $57 \pm 16$ years, and $56.2 \%$ were male [4,10-16]. Figure 1 illustrates the search process and study selection. Six trials initiated glucocorticoids treatment within 7 days of ARDS onset, while 2 trials initiated glucocorticoid treatment after 7 days of ARDS onset [11, 13]. Glucocorticoids were administered for a total of 7-14 days in five of the included trials. Two trials used extended duration of glucocorticoids (28-32 days) $[12,13]$. In addition, one trial administered high-dose methylprednisolone $(120 \mathrm{mg} / \mathrm{Kg}$ divided on 4 doses) for only $24 \mathrm{~h}$ [16]. Two studies were excluded from the final analysis due to high risk of bias concerning the blinding of participants and investigators

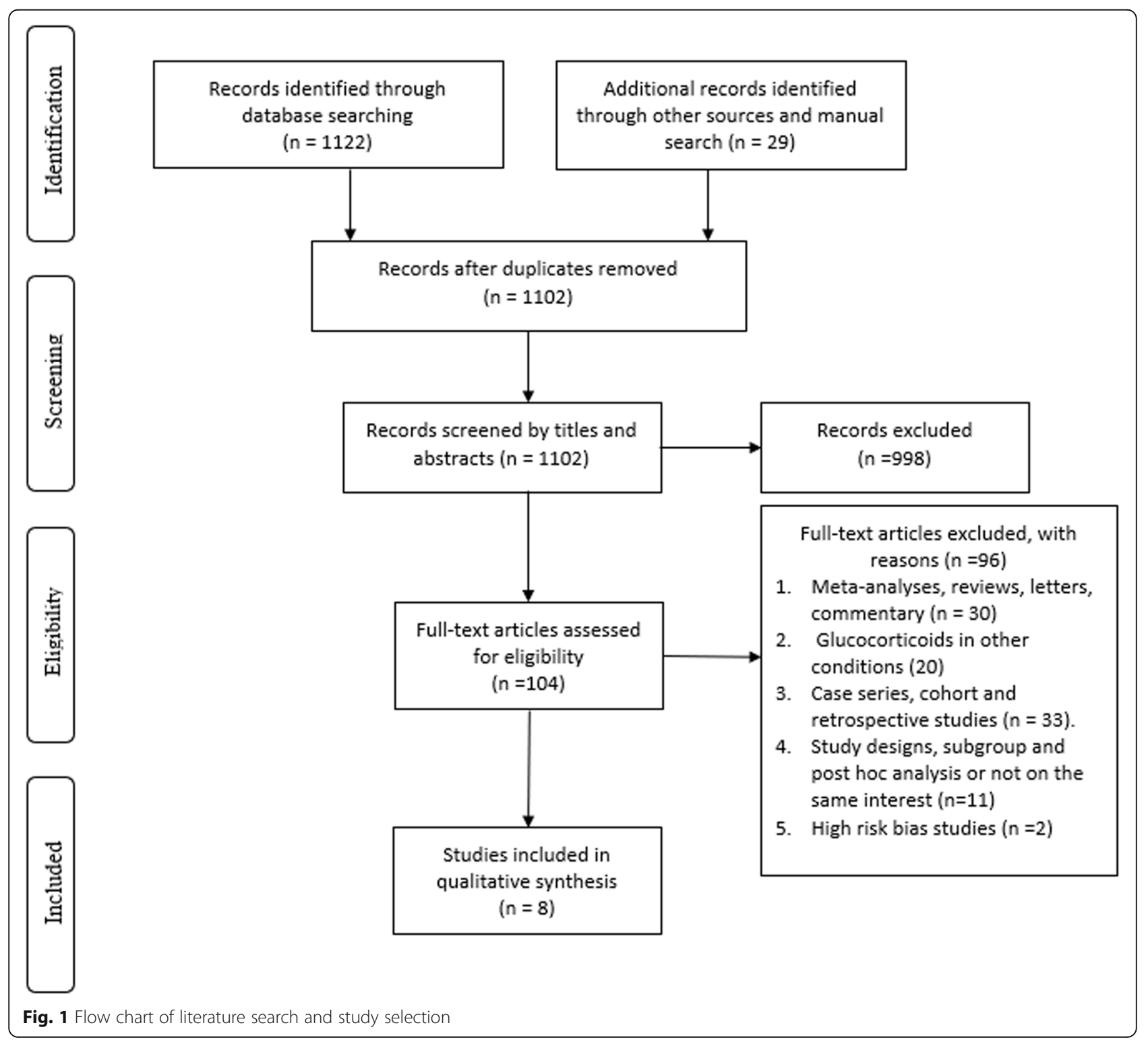


Table 1 Characteristics of included studies

\begin{tabular}{|c|c|c|c|c|c|c|}
\hline $\begin{array}{l}\text { Study name (first } \\
\text { author and year) }\end{array}$ & Study design & $\begin{array}{l}\text { Study groups and } \\
\text { patients' number }\end{array}$ & Inclusion criteria & Treatment regimen & $\begin{array}{l}\text { Duration of } \\
\text { treatment }\end{array}$ & $\begin{array}{l}\text { Follow-up } \\
\text { duration }\end{array}$ \\
\hline Bernard 1987 & $\begin{array}{l}\text { Multicenter } \\
\text { randomized } \\
\text { controlled trial }\end{array}$ & $\begin{array}{l}\text { Total patients, } 99 \\
\text { Steroids, } 50 \\
\text { Placebo, } 49\end{array}$ & $\begin{array}{l}\text { Adult patients having ARDS } \\
\text { withPaO2 } \leq 7 \text { Ommhg (with } \\
\mathrm{FiO} 2 \text { at least } 40 \% \text { ) or } \mathrm{PaO} 2 / \\
\mathrm{PAO} 2 \leq 0.3 ; \text { bilateral diffuse } \\
\text { infiltrates on chest } \\
\text { radiography, PAWP } \leq \\
18 \mathrm{~mm} \text { hg regardless of } \\
\text { PEEP level. }\end{array}$ & $\begin{array}{l}\text {-Treatment started after } \\
\text { ARDS onset. } \\
\text { Methylprednisolone } 30 \mathrm{mg} \\
\text { every } 6 \mathrm{~h} \text { ( } 4 \text { doses only). }\end{array}$ & $24 \mathrm{~h}$ & $\begin{array}{l}\text { Until death } \\
\text { or for } 45 \\
\text { days }\end{array}$ \\
\hline Meduri 1998 & $\begin{array}{l}\text { Multicenter } \\
\text { randomized } \\
\text { controlled trial }\end{array}$ & $\begin{array}{l}\text { Total Patients, } 24 \\
\text { Steroids, } 16 \\
\text { Placebo, } 8\end{array}$ & $\begin{array}{l}\text { Adult patients with hypoxemic } \\
\text { respiratory failure diagnosed } \\
\text { with ARDS, who were on } \\
\text { mechanical ventilation for at } \\
\text { least } 7 \text { days, with LIS of } 2.5 \text { or } \\
\text { greater and less than } 1 \text {-point } \\
\text { reduction from day } 1 \text { of ARDS } \\
\text { onset. }\end{array}$ & $\begin{array}{l}\text {-Treatment started after } 7 \text { days } \\
\text { of ARDS onset. } \\
\text {-Methylprednisolone } 2 \mathrm{mg} / \mathrm{kg} \\
\text { per day }(2 \mathrm{mg} / \mathrm{kg} \text { from day } 1 \\
\text { to day } 14 ; 1 \mathrm{mg} / \mathrm{kg} \text { from day } \\
15 \text { to } 21 ; 0.5 \mathrm{mg} / \mathrm{kg} \text { from day } \\
22 \text { to day } 28 ; 0.25 \mathrm{mg} / \text { day } \\
\text { from day } 28 \text { to day } 32) \text {. }\end{array}$ & 32 days & $\begin{array}{l}\text { Hospital } \\
\text { length of } \\
\text { stay. }\end{array}$ \\
\hline Confalonieri 2005 & $\begin{array}{l}\text { Multicenter } \\
\text { randomized } \\
\text { controlled trial }\end{array}$ & $\begin{array}{l}\text { Total patients, } 46 \\
\text { Steroids, } 22 \\
\text { Placebo, } 23\end{array}$ & $\begin{array}{l}\text { Patients with clinical and } \\
\text { radiographic evidence of } \\
\text { pneumonia with bilateral or } \\
\text { multi-lobar involvement and } \\
\mathrm{PaO} 2 / \mathrm{FiO} 2 \text { ratio less than } 250 \text {. }\end{array}$ & $\begin{array}{l}\text {-Treatment started after } \\
\text { diagnosis. } \\
\text {-Hydrocortisone } 200 \mathrm{mg} \\
\text { bolus followed by an } \\
\text { infusion of } 10 \mathrm{mg} / \mathrm{h} \text {. }\end{array}$ & 7 days & 60 days \\
\hline Annane 2006 & $\begin{array}{l}\text { Multicenter } \\
\text { randomized } \\
\text { controlled trial }\end{array}$ & $\begin{array}{l}\text { Total patients, } 177 \\
\text { Steroids, } 85 \\
\text { Placebo, } 92\end{array}$ & $\begin{array}{l}\text { Patients with septic shock and } \\
\text { ARDS; bilateral infiltrates on } \\
\text { chest radiography; } \mathrm{PaO} 2 / \mathrm{FiO} 2 \\
\leq 200 \text {, PAWP } \leq 18 \mathrm{mmh} \text { m; no } \\
\text { left atrial hypertension. }\end{array}$ & $\begin{array}{l}\text {-Treatment started after } \\
\text { randomization which occurred } \\
\text { within } 8 \mathrm{~h} \text { of disease onset. } \\
\text {-Hydrocortisone } 50 \text { mg every } \\
6 \mathrm{~h} \text { and } 9 \text { alpha } \\
\text { fludrocortisone } 50 \text { milligram } \\
\text { orally once a day. }\end{array}$ & 7 days & 28 days \\
\hline Steinberg 2006 & $\begin{array}{l}\text { Multicenter } \\
\text { randomized } \\
\text { control trial }\end{array}$ & $\begin{array}{l}\text { Total patients, } 180 \\
\text { Steroids, } 89 \\
\text { Placebo, } 91\end{array}$ & $\begin{array}{l}\text { Adult patients who had ARDS } \\
\text { and mechanically ventilated } \\
\text { for } 7 \text { to } 28 \text { days. PaO2/FiO2 } \\
\leq 200 \text { mmhg. }\end{array}$ & $\begin{array}{l}\text {-Treatment started after } 7 \\
\text { to } 28 \text { days of ARDS onset. } \\
\text {-Methylprednisolone: bolus } 2 \\
\mathrm{mg} / \mathrm{kg} \text { followed by } 0.5 \mathrm{mg} / \mathrm{kg} \\
\text { every } 6 \mathrm{~h} \text { for } 14 \text { days and then } \\
0.5 \mathrm{mg} / \mathrm{kg} \text { every } 12 \text { hours for } \\
7 \text { days and then tapering over } \\
4 \text { days. }\end{array}$ & 21-25 days. & 60 days \\
\hline Meduri 2007 & $\begin{array}{l}\text { Multicenter } \\
\text { randomized } \\
\text { control trial }\end{array}$ & $\begin{array}{l}\text { Total patients, } 91 \\
\text { Steroids, } 63 \\
\text { Placebo, } 28\end{array}$ & $\begin{array}{l}\text { Adult intubated patients with } \\
\text { early ARDS }(\leq 72 \mathrm{~h}) \text { defined } \\
\text { by the American-European } \\
\text { Consensus definition. }\end{array}$ & $\begin{array}{l}\text {-Treatment started within } \\
72 \mathrm{~h} \text { of ARDS onset. } \\
\text {-Methylprednisolone bolus } \\
\text { dose of } 1 \mathrm{mg} / \mathrm{kg} \text { followed by } \\
\text { an infusion of } 1 \mathrm{mg} / \mathrm{kg} \text { per } \\
\text { day from day } 1 \text { to day } 14 ; 0.5 \\
\mathrm{mg} / \mathrm{kg} \text { per day from day } 15 \text { to } \\
\text { day } 21 ; 0.25 \mathrm{mg} / \mathrm{kg} \text { per day } \\
\text { from day } 22 \text { to day } 25 \text {; and } \\
0.125 \mathrm{mg} / \mathrm{kg} \text { per day from } \\
\text { day } 26 \text { to day } 28 \text {. }\end{array}$ & Up to 28 days & $\begin{array}{l}\text { Hospital } \\
\text { length of } \\
\text { stay. }\end{array}$ \\
\hline Tongyoo 2016 & $\begin{array}{l}\text { Single-center } \\
\text { randomized } \\
\text { controlled trial }\end{array}$ & $\begin{array}{l}\text { Total patients, } 197 \\
\text { Steroids, } 98 \\
\text { Placebo, } 99\end{array}$ & $\begin{array}{l}\text { Adult patients with severe } \\
\text { sepsis or septic shock, } \\
\text { intubated with ARDS } \\
\text { (according to criteria of ARDS } \\
\text { by the American European } \\
\text { Consensus or by the berlin } \\
\text { criteria as moderate to severe } \\
\text { ARDS) }\end{array}$ & $\begin{array}{l}\text {-Randomization within } 12 \mathrm{~h} \\
\text { of ARDS onset. } \\
\text {-Hydrocortisone } 50 \mathrm{mg} \text { every } \\
6 \mathrm{~h} \text { for } 7 \text { days }\end{array}$ & 7 days & 28 days \\
\hline Villar 2020 & $\begin{array}{l}\text { Multicenter } \\
\text { randomized } \\
\text { control trial }\end{array}$ & $\begin{array}{l}\text { Total patients, } 277 \\
\text { Steroids, } 139 \\
\text { Placebo, } 138\end{array}$ & $\begin{array}{l}\text { Adult intubated patients } \\
\text { with acute onset of ARDS } \\
\text { according to criteria of ARDS } \\
\text { by the American European } \\
\text { Consensus or by the berlin } \\
\text { criteria as moderate to severe } \\
\text { ARDS. }\end{array}$ & $\begin{array}{l}\text { Dexamethasone } 20 \mathrm{mg} \text { daily } \\
\text { from day } 1 \text { to day } 5 \text {, then } 10 \\
\mathrm{mg} \text { daily from day } 6 \text { to } \\
\text { day } 10 .\end{array}$ & 10 days & 60 days \\
\hline
\end{tabular}


$[17,18]$. Table 1 explains the characteristics of included studies while Table 2 explains the demographic and clinical characteristics of the included patient populations in each study.

Figure 2 explains the results of the quality assessment based on authors' judgment.

\section{Clinical outcomes}

\section{Hospital and ICU-mortality}

Use of glucocorticoids was associated with a significant reduction of hospital mortality (RR 0.79 ; 95\% CI $0.64-$ 0.98; $P=0.03 ; I^{2}=47 \%$ ) and ICU mortality (RR 0.64; 95\% CI 0.42-0.97; $P=0.04, I^{2}$ 67\%) (Fig. 3). Sensitivity analysis with sequential trial removal revealed consistent results.

Subgroup analysis showed that there was no hospital mortality benefit with late administration (more than 7 days of ARDS onset) of glucocorticoids (RR 0.52; 95\% CI $0.11-2.52 ; P=0.42$; 2 studies, 204 patients) while mortality benefit remained significant with early glucocorticoids administration (RR 0.80; 95\% CI 0.65-0.98; $P=$ 0.03; 6 studies, 887 patients). Further subgroup analysis revealed that there was no significant difference in hospital mortality in studies that used glucocorticoids without lung protective ventilation (RR 0.79; 95\% CI 0.581.07; $P=0.12$; 6 studies, 667 patients), while the mortality reduction remained significant in studies incorporating a lung protective ventilation strategy (RR 0.75; 95\% CI $0.58-98 ; P=0.04 ; 2$ studies, 474 patients). Metaregression analysis did not suggest any effects of the study-level covariates on hospital mortality; however, prolonged duration of glucocorticoid treatment and higher PEEP were associated with decreased ICU mortality $(\mathrm{P}<0.05)$ (Supplementary Figure $1 \& 2$ ).

In a trial sequential analysis for hospital mortality, the cumulative Z-curve crossed the Alpha boundary of significance, indicating sufficient statistical significance favoring glucocorticoids over the control group. However, since the cumulative Z-curve failed to cross the TSA boundary and the diversity-adjusted information size (sample size) calculated (2692 patients) was not reached, the conclusion is insufficient, and further studies are needed (Fig. 4). Similarly, regarding ICU mortality, the conclusion was insufficient, and further studies are needed (Supplementary Figure 3). Similar conclusions were obtained upon performing sensitivity analyses with $15 \%$ and $25 \%$ RRR in mortality.

\section{Number ventilator-free days at day 28}

There was a significant increase in the number of ventilator-free days at day 28 in patients treated with glucocorticoids in comparison to the control group (MD 4.06 days; $95 \%$ CI 2.66-5.45; $P<0.01 ; I^{2}=25 \%$ ) (Fig. 5).

\section{Adverse events}

Use of glucocorticoids was not associated with an increased risk of hospital-acquired infections (RR 0.82; 95\% CI $0.68-1.00 ; P=0.05 ; I^{2}=3 \%$ ) but was associated with an increased risk of hyperglycemia (RR 1.11; $95 \%$ CI 1.01-1.24; $P=0.04 ; I^{2}=0 \%$ ) (Fig. 6). Meta-regression

Table 2 Baseline clinical characteristics of patients

\begin{tabular}{|c|c|c|c|c|c|c|c|c|}
\hline Study & Study groups & Total number & Age & Male No. (\%). & APACHE III score & Respiratory rate & $\mathrm{PaO} 2 / \mathrm{FiO} 2$ & PEEP \\
\hline \multirow[t]{2}{*}{ Bernard 1987} & Steroid & 50 & $55 \pm 2$ & NA & NA & NA & NA & $8 \pm 1$ \\
\hline & Control & 49 & $56 \pm 2$ & NA & NA & NA & NA & $7 \pm 1$ \\
\hline \multirow[t]{2}{*}{ Meduri 1998} & steroid & 16 & $47 \pm 3.9$ & $5(31 \%)$ & $58(14)$ & NA & $161(14)$ & $12(1.2)$ \\
\hline & control & 8 & $51 \pm 6.6$ & $4(50 \%)$ & $55(16)$ & NA & 141(19) & $14(1.7)$ \\
\hline \multirow[t]{2}{*}{ Confalonieri 2005} & steroid & 23 & $60.4 \pm 17.3$ & 17 (74\%) & $17.2 \pm 4.1$ & NA & $141 \pm 49$ & NA \\
\hline & control & 23 & $66.6 \pm 14.7$ & $15(65 \%)$ & $18.2 \pm 4$ & NA & $178 \pm 58$ & NA \\
\hline \multirow[t]{2}{*}{ Annane 2006} & steroid & 85 & $61 \pm 16$ & $56(66 \%)$ & NA & $18.5 \pm 3$ & $104 \pm 42$ & $6.8 \pm 2.7$ \\
\hline & control & 92 & $59 \pm 18$ & $65(70 \%)$ & NA & $17.9 \pm 3.1$ & $108 \pm 45$ & $7.4 \pm 3$ \\
\hline \multirow[t]{2}{*}{ Steinberg 2006} & steroid & 89 & $49 \pm 19$ & $40(45 \%)$ & $87.6 \pm 27.5$ & NA & $126 \pm 42$ & $12.9 \pm 5.6$ \\
\hline & control & 91 & $49.2 \pm 16.5$ & $58(64 \%)$ & $84.6 \pm 29.4$ & NA & $126 \pm 40$ & $12.3 \pm 4.7$ \\
\hline \multirow[t]{2}{*}{ Meduri 2007} & steroid & 63 & $50.1 \pm 15.3$ & 34 (54\%) & $60.2 \pm 20.2$ & NA & $118.4 \pm 51.2$ & $13 \pm 5$ \\
\hline & control & 28 & $53.2 \pm 15.3$ & $13(46 \%)$ & $57.9 \pm 21$ & NA & $125.9 \pm 38.6$ & $11.2 \pm 4$ \\
\hline \multirow[t]{2}{*}{ Tongyoo 2016} & steroid & 98 & $64.5 \pm 17.3$ & $50(51 \%)$ & $21.7 \pm 5.7$ & NA & $175.4 \pm 6.9$ & $7.3 \pm 3$ \\
\hline & control & 99 & $64.3 \pm 16$ & $51(52 \%)$ & $21.9 \pm 5.7$ & NA & $172.4 \pm 6.7$ & $6.8 \pm 2.5$ \\
\hline \multirow[t]{2}{*}{ Villar 2020} & steroid & 139 & $56 \pm 14$ & $96(69 \%)$ & NA & 23(5) & $142.4 \pm 37.3)$ & $12.6 \pm 2.7$ \\
\hline & control & 138 & $58 \pm 15$ & 95 (69\%) & NA & 23(5) & $143.5 \pm 33.4$ & $12.5 \pm 2.6$ \\
\hline
\end{tabular}

Data are provided number and percent (\%) or mean \pm SD. PaO2 partial pressure pf arterial oxygen, $P E E P$ positive end expiratory pressure, FiO2 fraction of inhaled oxygen, APACHE acute physiologic and chronic health evaluation 


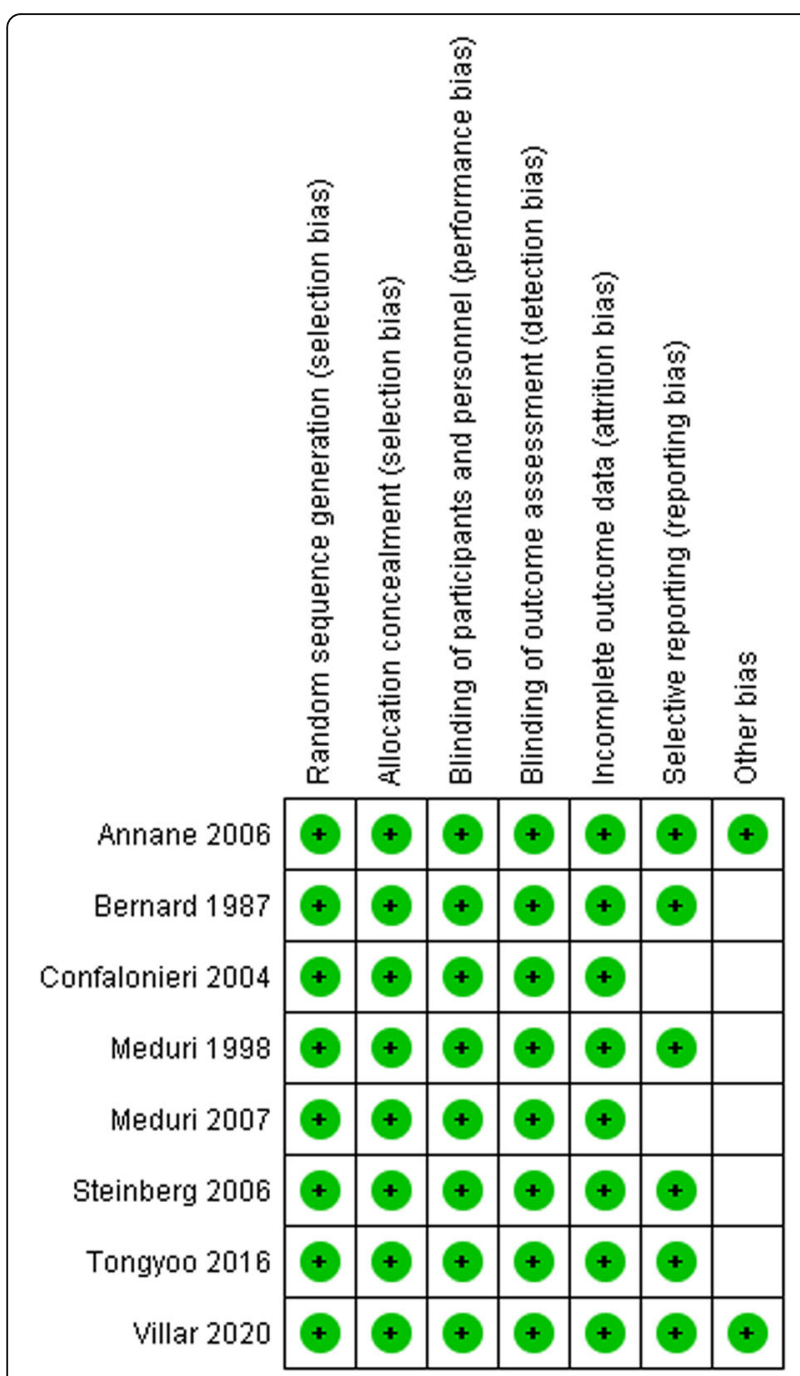

Fig. 2 Risk of bias assessment based on authors' judgment for each of the included RCTs. Blank items indicate an unclear risk of bias

analysis did not suggest any covariates effects on the adverse events.

\section{Discussion}

In our meta-analysis, use of glucocorticoids in patients with ARDS was associated with a significant reduction in hospital and ICU mortality and duration of mechanical ventilation. While there was no increased risk of hospital-acquired infections with glucocorticoid use, there was an increased risk of hyperglycemia. In trial sequential analysis, these findings could be secondary to a false-positive (type I) error, and further studies are needed for sufficient evidence as the required sample size was not reached by the available RCTs.

Current guidelines of American Thoracic Society/ European Society of intensive care medicine/Society of Critical Care Medicine have strong recommendations for the use of low tidal volume $(4-8 \mathrm{ml} / \mathrm{kg}$ of ideal body weight), limiting inspiratory pressure (plateau pressure < $30 \mathrm{~cm} \mathrm{H}_{2} \mathrm{O}$ ), and prone positioning in moderate-tosevere ARDS. Furthermore, the use of recruitment maneuvers and higher PEEP strategies have conditional recommendations in patients with moderate-to-severe ARDS. In addition, glucocorticoids have a conditional recommendation in early moderate-to-severe ARDS, and their use is still controversial $[6,19]$.

There are three distinct phases in the development of ARDS including exudative, proliferative, and fibrotic phases [1]. As lung fibrosis is associated with increased duration of mechanical ventilation and increased rates of mortality, steroids are considered a potent antiinflammatory agent that can attenuate the inflammatory process and subsequently decrease further lung injury and fibrosis [1].

A recently published randomized controlled trial revealed that early use of dexamethasone in patients with moderate-to-severe ARDS was associated with a significant reduction in mortality and duration of mechanical ventilation [4]. Similar results were noticed in patients with sepsis or septic shock with moderate-to-severe ARDS treated with methylprednisolone in comparison to placebo [10]. In these two recent trials, glucocorticoid use was evaluated with lung protective mechanical ventilation and low tidal volume, as opposed to the other trials conducted before 2005 where low tidal volumes were not implemented in the trial protocols. This strategy which limits tidal volume to $4-8 \mathrm{ml} / \mathrm{kg}$ of ideal body weight and alveolar pressure to less than $30 \mathrm{~cm} \mathrm{H}_{2} \mathrm{O}$ showed a significant reduction in mortality and increased number of ventilator-free days at day 28 [20].

In our subgroup analysis, we found that there was no mortality benefit in studies that evaluated glucocorticoids without a lung-protective ventilation strategy likely secondary to worsening lung injury. High tidal volumes delivered to an already injured lung may worsen lung injury leading to alveolar rupture, air leaks, and barotrauma with worse clinical outcomes [20-22]. Furthermore, we found that late administration of glucocorticoids (after 7 days of ARDS onset) was not associated with improved outcomes despite lower risk ratio (0.52) but with a high $p$ value, a finding that is limited by the low number of patients and studies in this subgroup (2 studies, 204 patients). However, this supports the concept that steroids exert their action through downregulation of the inflammatory response and decrease alveolar capillary permeability which occurs early in the exudative phase and is linked to lung injury [1]. In exploratory meta-regression, we found that patients who were treated with prolonged duration of glucocorticoid administration and received higher PEEP had lower ICU but not hospital mortality; a finding that is limited by 


\begin{tabular}{|c|c|c|c|c|c|c|c|c|c|c|}
\hline \multirow[b]{2}{*}{ Study or Subgroup } & \multicolumn{2}{|c|}{ Glucocorticoids } & \multicolumn{2}{|c|}{ Control } & \multirow[b]{2}{*}{ Weight } & \multicolumn{2}{|l|}{ Risk Ratio } & \multirow{2}{*}{\multicolumn{3}{|c|}{$\begin{array}{c}\text { Risk Ratio } \\
\text { M-H, Random, } 95 \% \mathrm{Cl}\end{array}$}} \\
\hline & Events & Total & Events & Total & & M-H, Random, $95 \% \mathrm{Cl}$ & Year & & & \\
\hline \multicolumn{11}{|c|}{ 1.1.1 Hospital mortality } \\
\hline Villar 2020 & 33 & 139 & 50 & 138 & $16.1 \%$ & $0.66[0.45,0.95]$ & 2020 & & & \\
\hline Tongyoo 2016 & 34 & 98 & 40 & 99 & $16.5 \%$ & $0.86[0.60,1.23]$ & 2012 & & & \\
\hline Meduri 2007 & 15 & 63 & 12 & 28 & $8.7 \%$ & $0.56[0.30,1.03]$ & 2007 & & & \\
\hline Annane 2006 & 54 & 85 & 67 & 92 & $24.5 \%$ & $0.87[0.71,1.07]$ & 2006 & $\rightarrow$ & & \\
\hline Steinberg 2006 & 26 & 89 & 26 & 91 & $12.8 \%$ & $1.02[0.65,1.62]$ & 2006 & & & \\
\hline Confalonieri 2004 & 0 & 23 & 8 & 23 & $0.6 \%$ & $0.06[0.00,0.96]$ & 2004 & . & & \\
\hline Meduri 1998 & 2 & 16 & 5 & 8 & $2.1 \%$ & $0.20[0.05,0.81]$ & 1998 & . & & \\
\hline $\begin{array}{l}\text { Bernard } 1987 \\
\text { Subtotal }(95 \% \mathrm{Cl})\end{array}$ & 30 & $\begin{array}{r}50 \\
563\end{array}$ & 31 & $\begin{array}{r}49 \\
528\end{array}$ & $\begin{array}{r}18.8 \% \\
100.0 \%\end{array}$ & $\begin{array}{r}0.95[0.69,1.29] \\
\mathbf{0 . 7 9}[\mathbf{0 . 6 4}, \mathbf{0 . 9 8}]\end{array}$ & 1987 & $\rightarrow$ & & \\
\hline Total events & 194 & & 239 & & & & & & & \\
\hline \multicolumn{11}{|c|}{$\begin{array}{l}\text { Heterogeneity: } \text { Tau }^{2}=0.04 ; \mathrm{Chi}^{2}=13.12, \mathrm{df}=7(\mathrm{P}=0.07) ; \mathrm{I}^{2}=47 \% \\
\text { Test for overall effect: } Z=2.17(\mathrm{P}=0.03)\end{array}$} \\
\hline \multicolumn{11}{|l|}{ 1.1.2 ICU-mortality } \\
\hline Villar 2020 & 26 & 139 & 43 & 138 & $24.5 \%$ & $0.60[0.39,0.92]$ & 2020 & $\rightarrow-$ & & \\
\hline Tongyoo 2016 & 22 & 98 & 27 & 99 & $22.7 \%$ & $0.82[0.50,1.34]$ & 2012 & - & & \\
\hline Meduri 2007 & 13 & 63 & 12 & 28 & $18.5 \%$ & $0.48[0.25,0.92]$ & 2007 & & & \\
\hline Annane 2006 & 53 & 85 & 62 & 92 & $30.1 \%$ & $0.93[0.74,1.15]$ & 2006 & $=$ & & \\
\hline Confalonieri 2004 & 0 & 23 & 7 & 23 & $2.1 \%$ & $0.07[0.00,1.10]$ & 2004 & $\leftarrow$ & & \\
\hline Meduri 1998 & 0 & 16 & 5 & 8 & $2.1 \%$ & $0.05[0.00,0.78]$ & 1998 & $\longleftarrow$ & & \\
\hline Subtotal $(95 \% \mathrm{Cl})$ & & 424 & & 388 & $100.0 \%$ & $0.64[0.42,0.97]$ & & & & \\
\hline \multirow{2}{*}{\multicolumn{11}{|c|}{$\begin{array}{l}\text { Total events } \quad 114 \quad 156 \\
\text { Heterogeneity: } \text { Tau }^{2}=0.14 ; \mathrm{Chi}^{2}=14.95, \mathrm{df}=5(\mathrm{P}=0.01) ; \mathrm{I}^{2}=67 \% \\
\text { Test for overall effect: } Z=2.10(\mathrm{P}=0.04)\end{array}$}} \\
\hline & & & & & & & & & & \\
\hline & & & & & & & & $\begin{array}{l}0.01 \\
\text { Favours glucacorticoids }\end{array}$ & $\begin{array}{c}10 \\
\text { Favours control }\end{array}$ & 100 \\
\hline
\end{tabular}

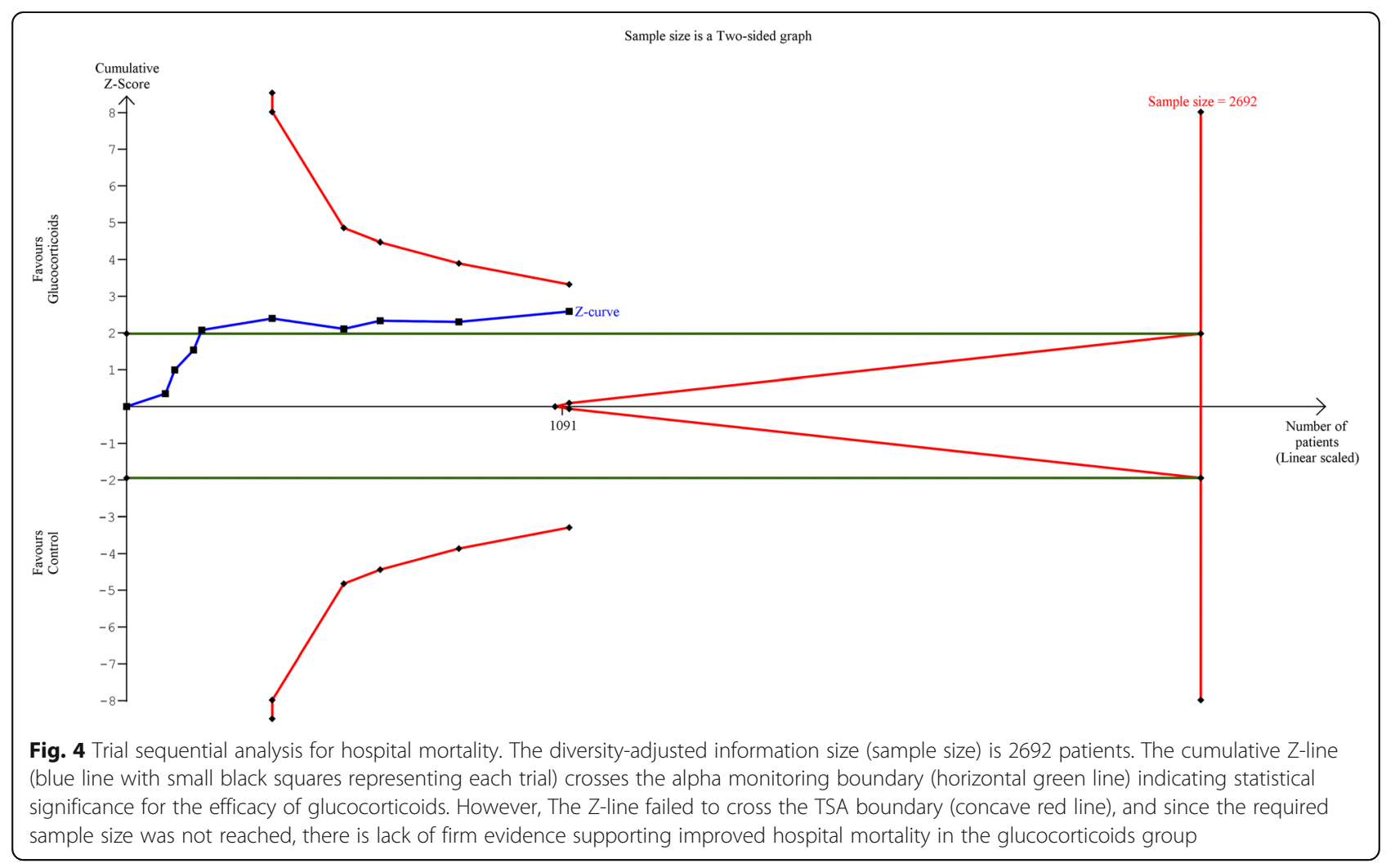




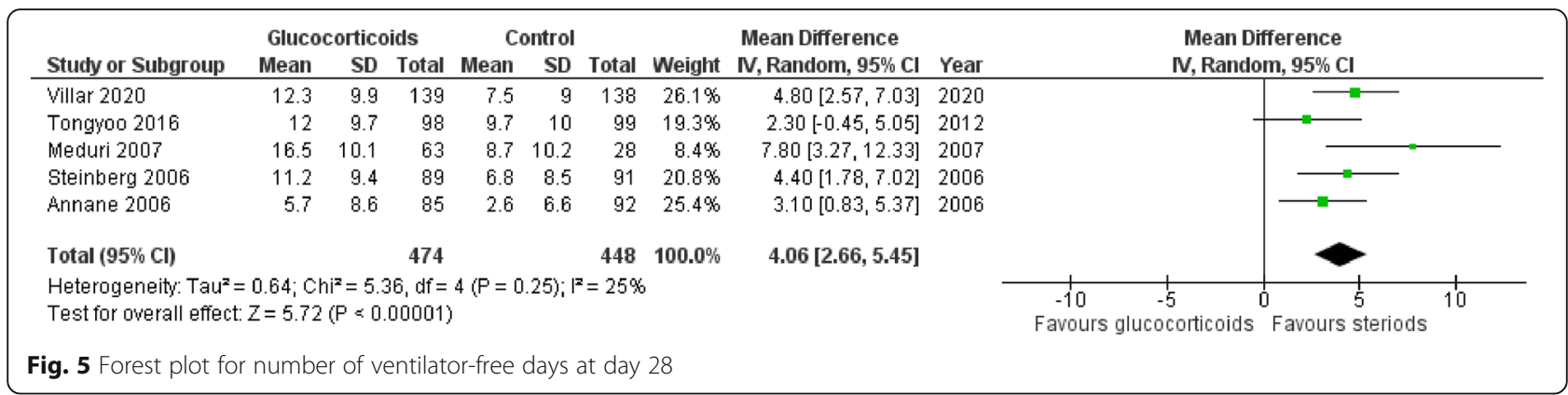

the low number of studies that reported ICU mortality and needs to be examined in further trials.

Our analysis revealed a $21 \%$ risk reduction in hospital mortality among ARDS patients treated with glucocorticoids with a number needed to treat of nine patients to prevent one death. In addition, there was a 4-day increase in the number of ventilator-free days at day 28 . Despite these favorable outcomes, there was no increased risk of hospital acquired infections; in contrast, our analysis showed a tendency toward reduction of acquired infections, a finding that could be explained by the decreased duration of mechanical ventilation and subsequently ICU length of stay. However, these findings should be interpreted cautiously until confirmed in further larger studies.

In order to examine the strength of the evidence and whether more randomized controlled trials are needed for sufficient conclusion regarding mortality benefit, we performed a trial sequential analysis to guard against false positive (type I) or false negative (type II) errors.
While the mortality benefit reached statistical significance, based on our analysis, the mortality benefit could be secondary to a false positive (type I) error, and the evidence is insufficient as the sample size required for detection of $20 \%$ RRR in mortality between the two groups while avoiding statistical errors is 2692 patients that was not reached by the available data (1091) patients were included in our analysis). Further, wellcontrolled randomized clinical trials are required for a strong conclusion about the efficacy of steroids in managing ARDS patients. Additionally, the focus should be on the type, dose, and duration of glucocorticoids therapy as we included studies that evaluated different glucocorticoids with variable dosages and durations. However, until further studies are performed, the significant risk reduction and the low number needed to treat may justify the use of glucocorticoids in patients with ARDS, especially those with an underlying etiology similar to patients enrolled in the included RCTs (sepsis, septic shock, and pneumonia).

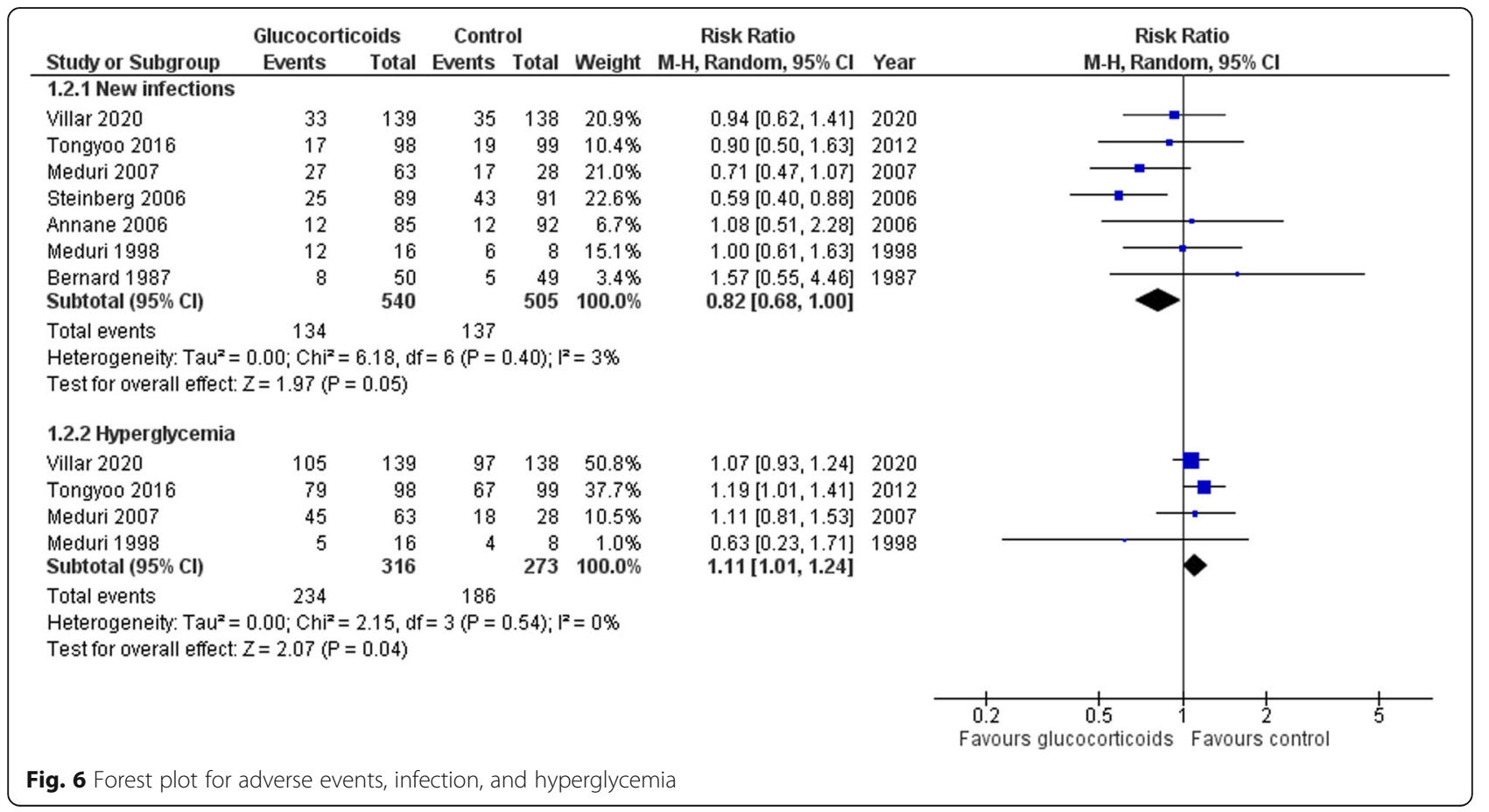


Our results are consistent with previously published meta-analyses. However, we included the recently published trial and only included patients with established ARDS, and we excluded studies with high risk of bias as well as retrospective studies which were included in previous reviews [23, 24]. Furthermore, we were able to perform subgroup and meta-regression analyses based on study-level covariates. In addition, we conducted trial sequential analysis to examine the strength of the evidence and concluded that further studies are needed for a strong and firm evidence of glucocorticoids efficacy in ARDS patients with paying special attention of the duration, dose, and timing of glucocorticoids administration.

Our results are non-generalizable to patients with ARDS secondary to coronavirus disease-2019 (COVID-19) and other viral pneumonias such as H1N1 influenza. To date, there is only one retrospective study that examined outcomes of COVID-19 patients treated with steroids. The study by $\mathrm{Wu}$ et al. found lower risk of death (hazard ratio 0.38; 95\% CI $0.20-0.72 ; p=0.003)$ in patients with ARDS treated with methylprednisolone [25]. In addition, a non-peer reviewed article was published recently and reported reduction in the duration of supplemental oxygen and improved radiographic findings in 26 patients with severe COVID-19 but it is unknown how many patients had ARDS in this cohort [26]. Since we lack patientlevel data and the information are missing in the published literature, we were unable to perform a subgroup analysis for patients with viral etiology of ARDS. However, it is known that glucocorticoids are associated with worse outcomes in patients with ARDS secondary to H1N1 influenza virus as demonstrated by previous cohort studies and meta-analyses [27-29]. Based on the current available evidence for the management of COVID-19 patients, Society of Critical Care Medicine and European Society of intensive care medicine guidelines have recommended against the use of corticosteroids in mechanically ventilated patients without ARDS and issued a weak recommendation for the use of low dose steroids (hydrocortisone $200 \mathrm{mg}$ per day) in those with ARDS and/or refractory septic shock [30].

\section{Limitations}

Our study has several limitations. There is significant advancement in critical care management between older and modern studies as most of the studies did not adopt lung-protective ventilation. Second, we included RCTs that investigated different types and dosages of glucocorticoids with various durations. Third, as we lack patientlevel data, we could not perform analyses based on the severity and underlying etiology of ARDS.

\section{Conclusion}

Among patients with ARDS, use of glucocorticoids is associated with significant reduction in mortality and duration of mechanical ventilation without an increased risk of infection but with an increased incidence of hyperglycemia. In our trial sequential analysis, we revealed that the evidence is insufficient from the available RCTs, and further studies are required for a firm conclusion with guarding against possible statistical errors.

\section{Supplementary information}

Supplementary information accompanies this paper at https://doi.org/10. 1186/s40560-020-00464-1.

Additional file 1: Supplementary Figure 1. Regression of duration of glucocorticoid treatment on ICU mortality. Longer duration was associated with lower rates of ICU mortality $(P<0.05)$.

Additional file 2: Supplementary Figure 2. Regression of PEEP on ICU mortality. Higher PEEP was associated with lower rates of ICU mortality $(P<0.05)$.

Additional file 3: Supplementary Figure 3. Trial sequential analysis for ICU-mortality. The diversity-adjusted information size (sample size) is 3,244 patients. The cumulative Z-line (blue line with small black squares representing each trial) crosses the alpha monitoring boundary (horizontal green line) indicating statistical significance for the efficacy of glucocorticoids. However, The Z-line failed to cross the TSA boundary (concave red line), and since the required sample size was not reached, there is lack of firm evidence supporting improved hospital mortality in the glucocorticoids group.

\section{Acknowledgements}

NA

\section{Authors' contributions}

YZ: study design, literature search, data analysis, data extraction, drafting the manuscript, and final approval of the manuscript. M.B.: study design, data analysis, drafting the manuscript, and final approval of the manuscript. E.I.: literature search, data extraction, drafting the manuscript, and final approval of the manuscript. V.S.: literature search, drafting the manuscript, and final approval of the manuscript. J.K..: data extraction, drafting the manuscript, and final approval of the manuscript. F.R.: drafting the manuscript and final approval of the manuscript. M.S.: literature search, drafting the manuscript, and final approval of the manuscript. A.B.: data analysis, literature search, drafting the manuscript, and final approval of the manuscript. M.O: literature search, drafting the manuscript, and final approval of the manuscript. S. Demian: data extraction, drafting the manuscript, and final approval of the manuscript. S. Deliwala: drafting the manuscript and final approval of the manuscript. I.A.: drafting the manuscript and final approval of the manuscript. R.R.: study design, data analysis, literature search, drafting the manuscript, and final approval of the manuscript.

Funding

There was no funding for this work.

Availability of data and materials

Data and materials are available and can be presented upon request.

Ethics approval and consent to participate

NA

Consent for publication

The authors give Journal of Intensive Care the consent for publishing this manuscript. There are no personal information that required consents. 


\section{Competing interests}

The authors have no competing interests to declare.

\section{Author details}

${ }^{1}$ Department of Internal Medicine, Hurley Medical Center/Michigan State University, One Hurley Plaza, Suite 212, Flint, MI 48503, USA. ${ }^{2}$ College of Human Medicine, Michigan State University, East Lansing, MI, USA. ${ }^{3}$ Department of Anesthesia, Lebanese University, Beirut, Lebanon. ${ }^{4}$ College of Osteopathic Medicine, Michigan State University, East Lansing, MI, USA. ${ }^{5}$ Department of Pulmonary and Critical Care, Hurley Medical Center/Michigan State University, Flint, MI, USA. 'Department of Pulmonary and Critical Care Medicine, University of Florida, Gainesville, FL, USA.

Received: 11 May 2020 Accepted: 22 June 2020

Published online: 30 June 2020

\section{References}

1. Thompson BT, Chambers RC, Liu KD. Acute respiratory distress syndrome. N Engl J Med [Internet]. 2017;377:562-72 Available from: http://www.ncbi.nlm. nih.gov/pubmed/28792873.

2. Bellani G, Laffey JG, Pham T, Fan E, Brochard L, Esteban A, et al. Epidemiology, patterns of care, and mortality for patients with acute respiratory distress syndrome in intensive care units in 50 countries. JAMA [Internet]. 2016;315:788-800 Available from: http://www.ncbi.nlm.nih.gov/ pubmed/26903337.

3. Ferguson ND, Fan E, Camporota L, Antonelli M, Anzueto A, Beale R, et al. The Berlin definition of ARDS: an expanded rationale, justification, and supplementary material. Intensive Care Med [Internet]. 2012;38:1573-82 Available from: http://www.ncbi.nlm.nih.gov/pubmed/22926653.

4. Villar J, Ferrando C, Martínez D, Ambrós A, Muñoz T, Soler JA, et al. Dexamethasone treatment for the acute respiratory distress syndrome: a multicentre, randomised controlled trial. Lancet Respir Med [Internet]. 2020; 8:267-76 Available from: http://www.ncbi.nlm.nih.gov/pubmed/32043986.

5. Meduri GU, Bridges L, Shih M-C, Marik PE, Siemieniuk RAC, Kocak M. Prolonged glucocorticoid treatment is associated with improved ARDS outcomes: analysis of individual patients' data from four randomized trials and trial-level meta-analysis of the updated literature. Intensive Care Med [Internet]. 2016;42:829-40 Available from: http://www.ncbi.nlm.nih.gov/ pubmed/26508525.

6. Annane D, Pastores SM, Rochwerg B, Arlt W, Balk RA, Beishuizen A, et al. Guidelines for the diagnosis and management of critical illness-related corticosteroid insufficiency (CIRCI) in critically ill patients (part I): Society of Critical Care Medicine (SCCM) and European Society of Intensive Care Medicine (ESICM) 2017. Crit Care Med [Internet]. 2017;45:2078-88 Available from: http://www.ncbi.nlm.nih.gov/pubmed/28938253.

7. Moher D, Shamseer L, Clarke M, Ghersi D, Liberati A, Petticrew M, et al. Preferred reporting items for systematic review and meta-analysis protocols (PRISMA-P) 2015 statement. Syst Rev [Internet]. 2015;4:1 Available from: http://www.ncbi.nlm.nih.gov/pubmed/25554246.

8. Higgins JPT, Altman DG, Gøtzsche PC, Jüni P, Moher D, Oxman AD, et al. The Cochrane Collaboration's tool for assessing risk of bias in randomised trials. BMJ [Internet]. 2011;343:d5928 Available from: http://www.ncbi.nlm. nih.gov/pubmed/22008217.

9. Wetterslev J, Jakobsen JC, Gluud C. Trial sequential analysis in systematic reviews with meta-analysis. BMC Med Res Methodol [Internet]. 2017;17:39 Available from: http://www.ncbi.nlm.nih.gov/pubmed/28264661.

10. Tongyoo S, Permpikul C, Mongkolpun W, Vattanavanit V, Udompanturak S, Kocak M, et al. Hydrocortisone treatment in early sepsis-associated acute respiratory distress syndrome: results of a randomized controlled trial. Crit Care [Internet]. 2016;20:329 Available from: http://www.ncbi.nlm.nih.gov/ pubmed/27741949.

11. Steinberg KP, Hudson LD, Goodman RB, Hough CL, Lanken PN, Hyzy R, et al. Efficacy and safety of corticosteroids for persistent acute respiratory distress syndrome. N Engl J Med [Internet]. 2006;354:1671-84 Available from: http:// www.ncbi.nlm.nih.gov/pubmed/16625008.

12. Meduri GU, Golden E, Freire AX, Taylor E, Zaman M, Carson SJ, et al. Methylprednisolone infusion in early severe ARDS: results of a randomized controlled trial. Chest [Internet], Available from. 2007;131:954-63 http:// www.ncbi.nlm.nih.gov/pubmed/17426195.

13. Meduri GU, Headley AS, Golden E, Carson SJ, Umberger RA, Kelso T, et al. Effect of prolonged methylprednisolone therapy in unresolving acute respiratory distress syndrome: a randomized controlled trial. JAMA [Internet] 1998:280:159-65 Available from: http://www.ncbi.nlm.nih.gov/pubmed/9669790.

14. Confalonieri M, Urbino R, Potena A, Piattella M, Parigi P, Puccio G, et al. Hydrocortisone infusion for severe community-acquired pneumonia: a preliminary randomized study. Am J Respir Crit Care Med [Internet]. 2005; 171:242-8 Available from: http://www.ncbi.nlm.nih.gov/pubmed/15557131.

15. Annane D, Sébille V, Bellissant E, Ger-Inf-05 Study Group. Effect of low doses of corticosteroids in septic shock patients with or without early acute respiratory distress syndrome. Crit Care Med [Internet]. 2006;34:22-30 Available from: http://www.ncbi.n/m.nih.gov/pubmed/16374152.

16. Bernard GR, Luce JM, Sprung CL, Rinaldo JE, Tate RM, Sibbald WJ, et al. High-dose corticosteroids in patients with the adult respiratory distress syndrome. N Engl J Med [Internet]. 1987;317:1565-70 Available from: http:// www.ncbi.nlm.nih.gov/pubmed/3317054.

17. Sabry N, Omar E. Corticosteroids and ICU Course of Community Acquired Pneumonia in Egyptian Settings. Pharmacology \& Pharmacy. 2011;2:73-81.

18. Rezk N, Ibrahim A. Effects of methylprednisolone in early ARDS. Egypt J Chest Dis Tuberc. 2013;62(1):167-72.

19. Fan E, Del Sorbo L, Goligher EC, Hodgson CL, Munshi L, Walkey AJ, et al. An official American Thoracic Society/European Society of Intensive Care Medicine/Society of Critical Care Medicine clinical practice guideline: mechanical ventilation in adult patients with acute respiratory distress syndrome. Am J Respir Crit Care Med [Internet]. 2017;195:1253-63 Available from: http://www.ncbi.nlm.nih.gov/pubmed/28459336.

20. Acute Respiratory Distress Syndrome Network, Brower RG, Matthay MA, Morris A, Schoenfeld D, Thompson BT, et al. Ventilation with lower tidal volumes as compared with traditional tidal volumes for acute lung injury and the acute respiratory distress syndrome. N Engl J Med [Internet]. 2000; 342:1301-8 Available from: http://www.ncbi.nlm.nih.gov/pubmed/10793162.

21. Carteaux G, Millán-Guilarte T, De Prost N, Razazi K, Abid S, Thille AW, et al. Failure of noninvasive ventilation for de novo acute hypoxemic respiratory failure: role of tidal volume. Crit Care Med [Internet]. 2016;44:282-90 Available from: http://www.ncbi.nlm.nih.gov/pubmed/26584191.

22. Slutsky AS, Ranieri VM, et al. N Engl J Med [Internet]. 2013;369:2126-36 Available from: http://www.ncbi.nlm.nih.gov/pubmed/24283226.

23. Zhao Q, Shi J-X, Hu R, Li Q, Zhang C-Y, Li J-S, et al. Exp Ther Med [Internet]. 2019;18:4913-20 Available from: http://www.ncbi.n/m.nih.gov/pubmed/31 807156

24. Sun S, Liu D, Zhang H, Zhang X, Wan B. Effect of different doses and timecourses of corticosteroid treatment in patients with acute respiratory distress syndrome: a meta-analysis. Exp Ther Med [Internet]. 2019;18:463744 Available from: http://www.ncbi.nlm.nih.gov/pubmed/31807150.

25. Wu C, Chen X, Cai Y, Xia J, Zhou X, Xu S, et al. Risk factors associated with acute respiratory distress syndrome and death in patients with coronavirus disease 2019 pneumonia in Wuhan, China. JAMA Intern Med [Internet]. 2020; Available from: http://www.ncbi.n/m.nih.gov/pubmed/32167524.

26. Wang Y, Jiang W, He Q, Wang C, Wang B, Zhou P, Dong N TQ. Early, lowdose and short-term application of corticosteroid treatment in patients with severe COVID-19 pneumonia: single-center experience from Wuhan, China. medRxiv. 2020;2003.2006.

27. Lansbury L, Rodrigo C, Leonardi-Bee J, Nguyen-Van-Tam J, Lim WS. Corticosteroids as adjunctive therapy in the treatment of influenza. Cochrane Database Syst Rev [Internet]. 2019;2:CD010406 Available from: http://www.ncbi.nlm.nih.gov/pubmed/30798570.

28. Brun-Buisson C, Richard J-CM, Mercat A, Thiébaut ACM, Brochard L. REVASRLF a/H1N1v 2009 registry group. Early corticosteroids in severe influenza a/H1N1 pneumonia and acute respiratory distress syndrome. Am J Respir Crit Care Med [Internet]. 2011;183:1200-6 Available from: http://www.ncbi. nlm.nih.gov/pubmed/21471082.

29. Ruan S-Y, Lin H-H, Huang C-T, Kuo P-H, Wu H-D, Yu C-J. Exploring the heterogeneity of effects of corticosteroids on acute respiratory distress syndrome: a systematic review and meta-analysis. Crit Care [Internet]. 2014; 18:R63 Available from: http://www.ncbi.nlm.nih.gov/pubmed/24708846.

30. Alhazzani W, Møller MH, Arabi YM, Loeb M, Gong MN, Fan E, et al. Surviving Sepsis Campaign: guidelines on the management of critically ill adults with coronavirus disease 2019 (COVID-19). Intensive Care Med [Internet]. 2020; Available from: http://www.ncbi.nlm.nih.gov/pubmed/32222812.

\section{Publisher's Note}

Springer Nature remains neutral with regard to jurisdictional claims in published maps and institutional affiliations. 